INDEPENDENT JOURNAL OF MANAGEMENT \& PRODUCTION (IJM\&P)

http://www.ijmp.jor.br

v. 9, n. 2, April - June 2018

ISSN: 2236-269X

DOI: 10.14807/ijmp.v9i2.689

\title{
EMERGING TRENDS AND COLLABORATIVE NETWORK PATTERNS ON REVERSE LOGISTICS
}

Marina Pires de Lima Simão State University of Maringá (UEM), Brazil

E-mail: mplsimao@gmail.com

Danilo Hisano Barbosa State University of Maringá (UEM), Brazil E-mail:dhbarbosa@uem.br

Juliana Sayuri Kurumoto State University of Maringá (UEM), Brazil

E-mail: jskbarbosa2@uem.br

Gislaine Camila Lapasini Leal State University of Maringá (UEM), Brazil E-mail: gclleal@uem.br

Edwin Vladimir Cardoza Galdamez State University of Maringá (UEM), Brazil E-mail: evcgaldamez@uem.br

Syntia Lemos Cotrim State University of Maringá (UEM), Brazil E-mail: slcotrim2@uem.br

Submission: $12 / 07 / 2017$ Accept: 02/03/2018

\section{ABSTRACT}

Reverse Logistics includes the planning, implementation and control of the reverse flow of post-sales and post-consumption goods. The purpose of this article is to identify emerging collaborative networks and scientific areas on Reverse Logistics (RL) using temporal, geospatial and topical analyses. The study is based on the bibliometric networks analysis, a technique used to measure scientific development, production indexes and dissemination of knowledge. The main results of the research stand out the relationship of knowledge areas and scientific gaps, the identification of the main authors and the aspects related to the social network of cooperation of the authors such as country 
INDEPENDENT JOURNAL OF MANAGEMENT \& PRODUCTION (IJM\&P)

http://www.ijmp.jor.br

v. 9, n. 2, April - June 2018

ISSN: 2236-269X

DOI: 10.14807/ijmp.v9i2.689

citation and network density.

Keywords: reverse logistics; social network analysis; collaborative networks

\section{INTRODUCTION}

Reverse Logistics is a segment of Logistics focused on the movement and management of products and resources in the post-sale and post-consumption (CSCMP, 2015). The application of the reverse logistics system has grown as consumers' demands on the social, economic and environmental impacts of products and packaging discarded by society increase. It is a process being applied in several industrial areas such as the plastics industry, packaging and tires.

The demand for innovative solutions for the industry motivates scientific and technological production. It is a production of knowledge observed from the evolution of publication indicators of scientific articles. These references provide knowledge for the implementation, modeling, evaluation and maintenance of Reverse Logistics Systems.

Reverse Logistics has become increasingly important due to growing concern about environmental issues, legislation, social responsibility and sustainable competitiveness (AGRAWAL et al., 2015; RAVl; SHANKAR, 2005). Govindan et al. (2012) point out that Reverse Logistics is adopted as a strategic tool to generate competitive advantage, both in terms of economic benefits and corporate social image. Da Silva et al. (2017) complement that RL concern is not only environmental, but also of adding value to the product, or minimizing the use of raw materials incorporating post-consumer waste, and ensuring the proper destination of what can't be reused.

The frontier between direct and reverse logistics is not strictly defined, since the concepts of raw material and final customer can be relativized in some productive chains (ADLMAIER; SELLITTO, 2007). Moraes et al. (2015) claim that the term reverse logistics has been employed with widely varying meanings.

To consider the growth observed in the area of Reverse Logistics and to analyze the trends about the practice there are several forms of analysis, among them the Bibliometric Networks. Bibliometric analysis is a quantitative and statistical technique used to measure production indexes and dissemination of knowledge, as 
INDEPENDENT JOURNAL OF MANAGEMENT \& PRODUCTION (IJM\&P)

http://www.ijmp.jor.br

v. 9, n. 2, April - June 2018

ISSN: 2236-269X

DOI: 10.14807/ijmp.v9i2.689

well as accompanying scientific development in several areas or patterns of authorship, publication and use of research results, helping researchers to identify patterns that can influence the decision-making process of the research (COSTA et al., 2012; DAIM et al., 2006).

The Social Network Analysis (SNA) is a distinct subarea of research that science uses as a complement to studies in the field of bibliometry (SILVA, 2006). It is applied to phenomena in which the importance lies in the relations between actors that interact in these phenomena (FARINA, 2004).

Facing the expressed problematic, it is observed that there are studies such as authors Autry et al. (2001), Pokharel and Mutha (2009) and Govindan et al. (2015), who carried out analysis of the Business Logistics using the systematic review and bibliometric analysis, however, rarely based on the analysis of bibliometric networks.

The objective of this study is to identify emerging scientific and technological areas on Reverse Logistics using bibliometric networks. In addition, temporal, geospatial and topical analyses were carried out from the softwares Sci2Tool and CiteSpace.

The Analysis of Social Networks of the authors through the indicators of scientific production allows to determine the relations with technological and social development and to identify the relationship of the knowledge areas of Reverse Logistics \& Engineering, Operations Research \& Management Science, Business \& Economics and Management. With the research it is also possible to draw gaps or new scientific opportunities that are emerging between Reverse Logistics and Environmental Sciences, Green Sustainable Science Technology and Computer Science Artificial Intelligence.

The paper is structured in four sections, besides this introductory section. Section 2 describes the methodological procedures adopted. In Section 3 the theoretical reference is described, addressing reverse logistics and bibliometric analysis. Section 4 presents the results obtained. Finally, in Section 5 the conclusion is presented, highlighting the contributions and limitations of this study.

\section{METHODOLOGICAL PROCEDURES}


Figure 1 illustrates the methodological procedures adopted, highlighting the steps (Data Collection, Processing and Analysis) followed, activities involved and their chaining.

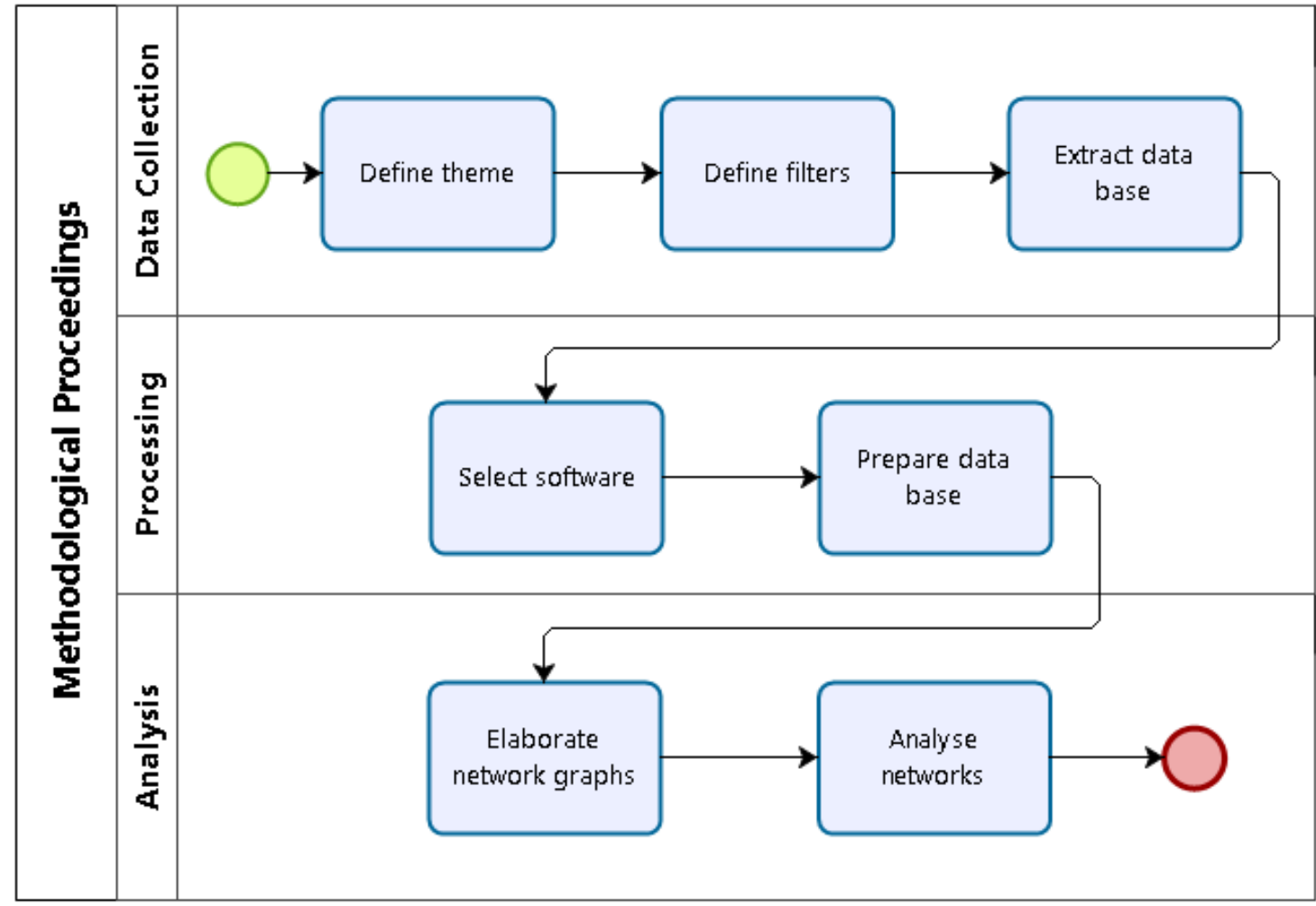

Figure 1: Methodological procedures adopted.

The Data Collection stage aims to prepare the data for processing by software of bibliometric analysis and involves the following activities

- Define the theme: this activity involves the definition of the topic to be approached. It is important to emphasize that this definition must have terminological precision in the scientific field.

- Define filters: this activity directs the search of the publications, through the definition of databases and search filters to be used. The filters used were: Research Areas (Science Technology and Others Topics, Engineering, Transportation, Business Economics and Operations Research Management Science); Types of Document (Articles); And finally, publications that are only part of the Web of Science database.

- Extract database: This activity is the initial step to open the network analysis and aims to create the database. Data was extracted in April 2016 from the Web of Science platform and the formulated database contained 
841 documents.

The Processing stage aims to prepare the database and the formulation of the graphs and involves the following activities:

- Select the software: this activity allows the study of the software available for the elaboration of network graphs, identifying which types of networks can be generated and how to produce them. For this study, the software CiteSpace and Sci2Tool were selected.

- Prepare database: this activity aims to prepare the Database for compatibility with the software used.

The objective of the Analysis stage is to perform the analytical treatment of the graphs in a fragmented and systemic way, relating it to the unit of analysis of the research, Reverse Logistics and its aspects. This stage involved the following activities:

- Draw network graphs: this activity aims to determine the types of networks that are pertinent to the study and generate the network graphs. In this activity, CiteSpace was used to graphically identify the evolution of the literature, and still detect and visualize the emergence of trend and radical changes in the literature in a given timing period, following the assumptions Chen et al. (2006). The following graphs were obtained from CiteSpace: CoAuthoring Network, Co-Occurrence Network of Research Areas and CoAuthoring Networks by country. In addition, Sci2Tool software was used to obtain the Network of Quotations and Network of Co-Quotations.

- Analyse the networks: this activity involves the study of the interpretation types that can be generated in each of the networks. In addition, this activity aims to find connections between the networks that have been produced, how they can interconnect with each other and with the study, the common factors that are relevant, and what interpretations can be done, and so on. The Sci2Tool software was used for the analysis and visualization of bibliometric networks under the temporal, geospatial and topical perspectives, as highlighted by SciTeam (2009).

\section{REVERSE LOGISTICS}


INDEPENDENT JOURNAL OF MANAGEMENT \& PRODUCTION (IJM\&P)

http://www.ijmp.jor.br

v. 9, n. 2, April - June 2018

ISSN: 2236-269X

DOI: 10.14807/ijmp.v9i2.689

Reverse Logistics is the process of planning, implementing and controlling the efficient and effective flow of obsolete materials such as raw material, process inventory, finished products and related information, from the point of consumption to the point of origin, for the purpose of recapturing value or proper disposal (ROGERS; TIBBEN-LEMBKE, 1998; ROGERS; TIBBEN-LEMBKE, 2001; SHERIFF; GUNASEKARAN; NACHIPPAN, 2012).

Reverse Logistics is subdivided into two components: post-consumption and post-sale (FLEISHMANN, 2000). Reverse Logistics post-sale has as strategic objective to add value to a logistics product that is returned for commercial reasons, errors in order processing, manufacturer's warranty, defects or malfunctions in the product, transportation breakdown, among other reasons, and consists of end-ofuse return, commercial return, guarantee return, scrap production and byproducts, and packaging (DU; EVANS, 2008).

The end-of-use return are those goods discarded after their use is completed, commercial return is referred to the return of products undoing a previous trade, warranty return are the goods that have failed during use, or damaged during delivery and return to the original sender. Scrap production and byproducts refers to the excess materials in the production process, and finally the packaging, which can be as example reusable bottles and pallets (FLEISHMANN, 2000).

Post-consumer Reverse Logistics aims to add value to a logistic product made up of goods that were useless to the original owner, or that still have conditions of use, for products that have been discarded because they have reached the end of their useful lives and for industrial waste. This includes five recovery options: repair, remodeling, remanufacturing, cannibalization and recycling (THIERRY et al., 1995).

\section{BIBLIOMETRIC ANALYSIS}

According to Pritchard (1969), the term bibliometric is used for the application of mathematical and statistical methods for books and other means of communication. In addition, the creation of significant and rigorous indicators is a complex activity. However, it is important to emphasize the growing importance that indicators of scientific production are gaining as instruments for the analysis of scientific activity and its relations with economic and social development (KOBASHI; 
SANTOS, 2006). The authors also point out the occurrence of expressive set of bibliometric indicators used in the analysis of scientific production, as follow:

- Scientific production indicators: constructed by counting the number of publications by document type, by institution, area of knowledge, country, etc.

- Citation Indicators: constructed by counting the number of citations received by an article published in a journal (most recognized way of assigning credit to the author).

- Connection indicator: built by the co-occurrence of authorship, citations and words, being applied in the elaboration maps of knowledge structures and networks of relationships between researchers, institutions and countries.

- Indicators of scientific quality: constructed from the perception and opinion of peers who evaluate publications according to their content.

- Indicators of scientific activity: based on the accounting of scientific activities developed, namely the number and distribution of published papers, author productivity, collaboration in authorship, number and distribution of references between studies and authors, among others.

- Scientific Impact Indicators: constructed from two subgroups, research impact indicators where the number of citations received and indicators of the sources impact are indicated; where that is the impact factor of journals, index of immediate citation and influence of journals.

- Indicators of thematic associations: built from analysis of citations and references.

In addition to these indicators, bibliometric analysis occurs from various perspectives, including interpretations from temporal, geospatial, and topical analysis. The Temporal Analysis intends to identify the nature of the phenomena represented by a sequence of observations, such as patterns, trends, seasonality, outliers and explosions of activity. Geospatial Analysis answers questions such as where something happens and what impact it has in neighborhood areas. Topical Analysis extracts a set of unique words or word profiles and their frequency from the body of a text; Network Analysis, the main focus of the study, is based on the 
analysis of social networks, physics, information science, bibliometric, scientometry, econometrics, infometrics, webometric, communication theory, sociology of science and several other disciplines (WEINGART et al., 2010).

\section{RESULTS}

In the sequence are the results on the analysis of co-occurrence networks of categories, co-authorship and citations. The main objectives are to identify the relationships and gaps of the categories or areas of knowledge developed, to identify the social network of authors from the scientific production and to identify relevant factors of the exchanges or collaborations carried out by the scientific community in the area of Reverse Logistics, among others.

\subsection{Analysis of the category co-occurrence network}

Co-occurrence Network Analysis uses co-occurrence patterns of pairs of items, i.e., words or phrases to identify the relationship between ideas within an area present in the text (HE, 1999). This analysis allows a new researcher in an area to become instantly familiar, facilitating the identification of key themes and their relationships, in addition to discovering and describing the interaction between different research fields (MUÑOZ-LEIVA et al., 2012). The graphical representation on the Analysis of the Categories Co-occurrence Network is highlighted in Figure 2.

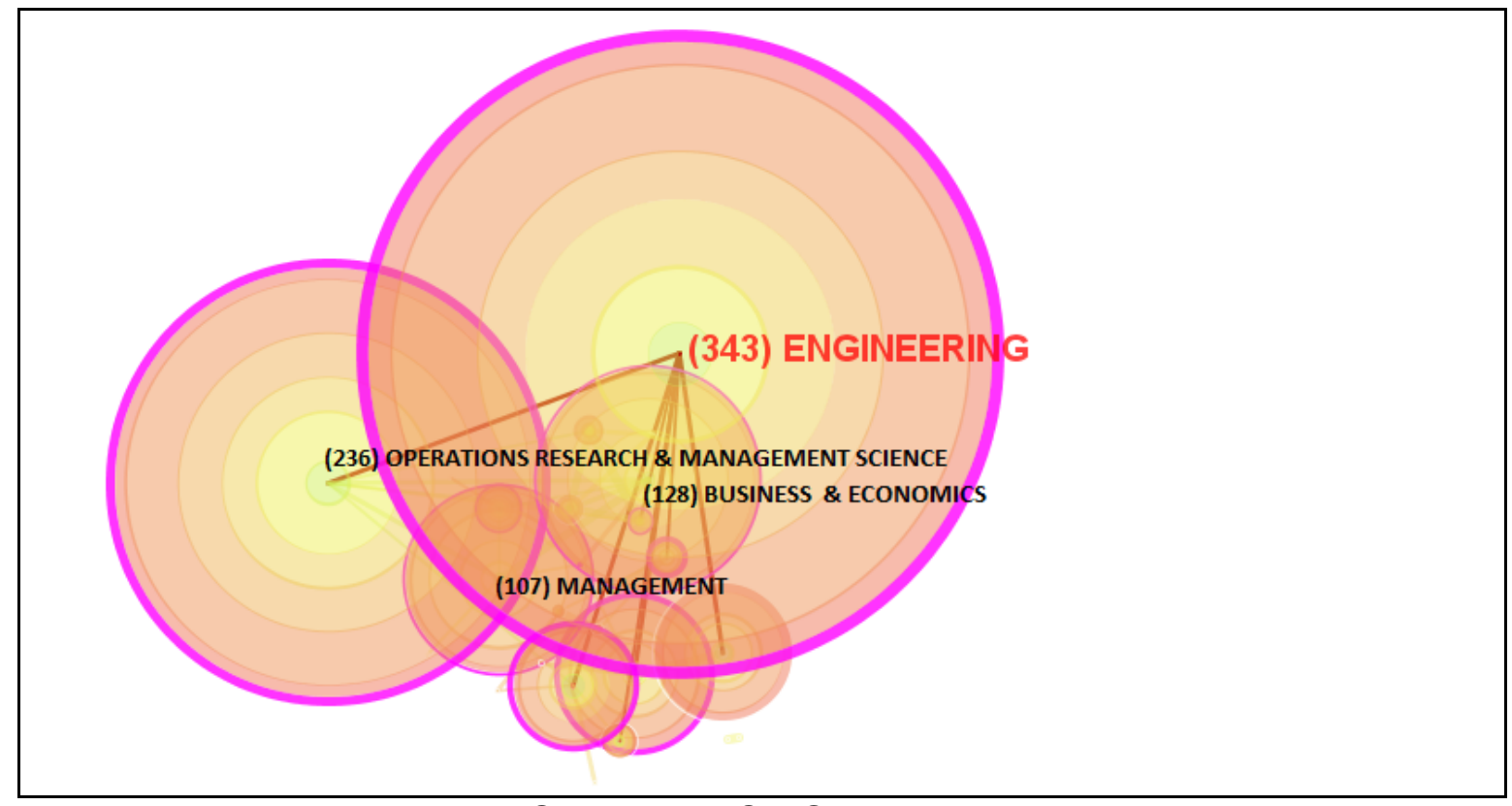

Figure 2: Categories Co-Occurrence Network 
INDEPENDENT JOURNAL OF MANAGEMENT \& PRODUCTION (IJM\&P)

http://www.ijmp.jor.br

v. 9, n. 2, April - June 2018

ISSN: 2236-269X

DOI: 10.14807/ijmp.v9i2.689

The areas of research with more occurrence were Engineering, Operations Research \& Management Science, Business \& Economics and Management. It is noted that research fronts are correlated, since Engineering strives to achieve results by designing economically and technically feasible solutions. Operations Research \& Management Science enables more effective decision making, and builds more efficient systems, Business \& Economics deals with the organization, management, expansion and strategy, and finally Management promotes the planning, control and improvement of the processes involved in Reverse Logistics.

The incidence of Categories (Engineering, Operations Research \& Management Science, Business \& Economics and Management) demonstrates a complementarity of methods and practices developed in the areas for the Reverse Logistics process. In addition, the most cited articles and authors that have the greatest influence in the area are allocated in these categories.

The network analysis also indicates a density degree of 0.1262 , which implies a low degree of direct interconnection between the agents and characterizes the network as diffuse. As pointed out by Gnyawali and Madhavan (2001) and Sacomano Neto (2004), diffuse networks provide innovation due to the nonredundant character between nodes.

It is also possible to observe that other focuses of study have also arisen since the Reverse Logistics can be applied in diverse scopes. In the future and with the feasibility of correlating Reverse Logistics with different areas of knowledge, it is possible that the network characteristic of being diffuse changes and becomes a dense network. From an analysis performed on the Web of Science platform it is observed that the areas Environmental Sciences, Green Sustainable Science Technology and Computer Science Artificial Intelligence are emerging in the theme and have different coverage of the pioneers on the subject.

From the Environmental Sciences category, it is observed several studies related to sustainability, green supply chain management, hybrid systems, waste management and other concepts, but always focused on environmental conservation. In addition, it is noted that some approaches deal with postconsumption and post-sales practices such as remanufacturing, remodeling, end-ofuse return, recycling, among others, which demonstrates that Thierry (1995) and 
INDEPENDENT JOURNAL OF MANAGEMENT \& PRODUCTION (IJM\&P)

http://www.ijmp.jor.br

v. 9, n. 2, April - June 2018

ISSN: 2236-269X

DOI: 10.14807/ijmp.v9i2.689

Fleishmann (2000) already presented concepts that would be of great relevance for the development of studies.

In the Green Sustainable Science Technology area, study approaches are similar to the above category, and many articles fitting within this category are noted to similarly fit under Environmental Sciences. Such a characteristic can be due to the affinity of both fields.

Another front of study that has been emerging from the technological advances of the area of Computation and that increasingly seeks automation is that of Computer Science Artificial Intelligence. In this area, the authors focus on algorithm studies for problem solving, programming model development, program management, among others, which are usually focused on computation. One aspect that can be examined is the tendency of several works to mention points such as green logistics, sustainable waste management, green transport and development of green practices, which emphasizes the growth that environmental practices have been happening, as well as concern with post-consumption and post-sales.

\subsection{Analysis of the co-authorship network}

Figure 3 highlights the Co-Authorship Network. According to ZareFarashbandi et al. (2014), authors through their participation in one or more publications indirectly demonstrate links between them in this social network.

It is noted that most of the actors in the network do not present any type of connection, reflecting the lack of scientific collaboration on the subject. According to Lima (2009), there are innumerable causes directly or indirectly related to the structural evolution of co-authorship networks, so it is only necessary to restrict the analysis to specific elements such as lines, projects and research groups to which the network actors are linked. Following this line of reasoning, what may be the possible causes of this low adherence to the association of studies? Some factors can be punctuated as weak incentive to share ideas, geospatial factors and reasons for topical divergence.

It is also indicated in Figure 3 the most significant loops of the network (circle). The following social network of authors forms the group that shows the highest density: Kannan Govindan (University of Southern Denmark), Devika Kannan (Aalborg University), Ali Diabat (North Carolina State University) and Joseph Sarkis 
INDEPENDENT JOURNAL OF MANAGEMENT \& PRODUCTION (IJM\&P)

http://www.ijmp.jor.br

v. 9, n. 2, April - June 2018

ISSN: 2236-269X

DOI: 10.14807/ijmp.v9i2.689

(Worcester Polytechnic Institute) - highlighted in Figure 4. The network in which they are inserted is of strong connection and dense, and has as central actor Kannan Covindan, because it has non-directional relation (knowledge, co-authorship), that is, reciprocal relationship with each one of the authors cited.

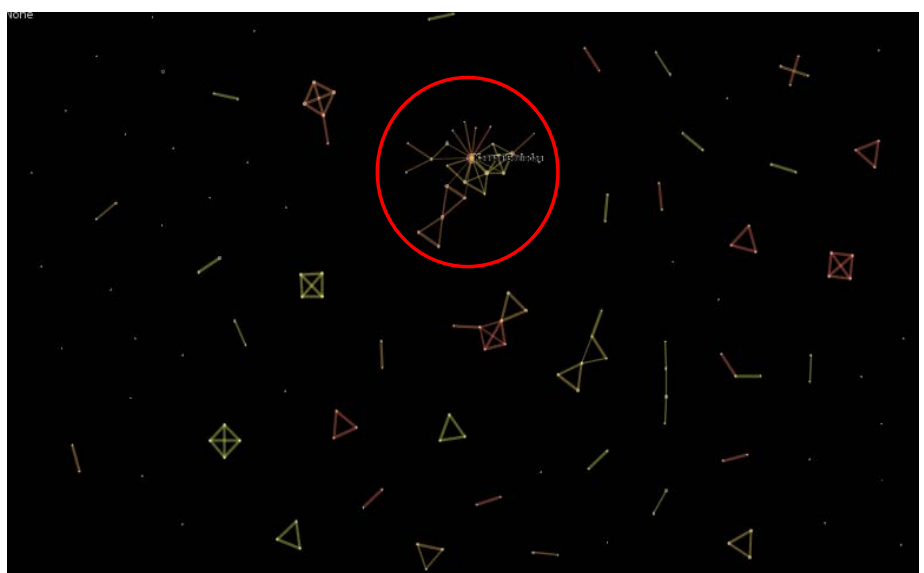

Figure 3: Co-Authoring Network

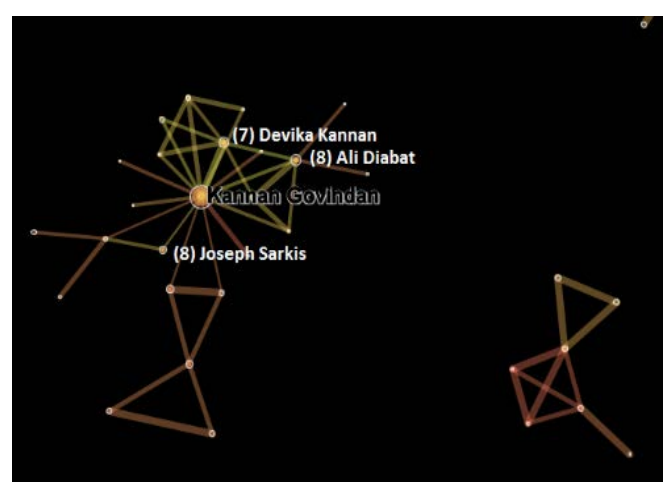

Figure 4: Nucleus of Higher Density of the Co-Authorship Network

Analyzing other aspects of the network's most significant relationships, it is recognized that the link between Devika Kannan and Kannan Govindan (21 coauthors) may have a geospatial character, which favors the bonding between them and facilitates the conservation of the link. The character of a network is not restricted only to geospatial factors and can be seen in the central actor's connection with Ali Diabat (9 co-authors) and Joseph Sarkis (10 co-authors). The relational link between them may be topical, explained by the interest in similar approaches to the topic or a joint research group.

\subsection{Analysis of the country co-authoring network}

Figure 5 illustrates the Analysis of the Co-authoring Network by Country, it is noticed that it is a network with dense interconnection presenting as central actor the United States. Other relevant countries in the network structure are Canada, China and Iran. Evidence that may result in the prominence of these countries is the number of Technology-Based Companies (TBC's) that generate new business models and develop innovations, requiring interdisciplinary of Knowledge areas. 


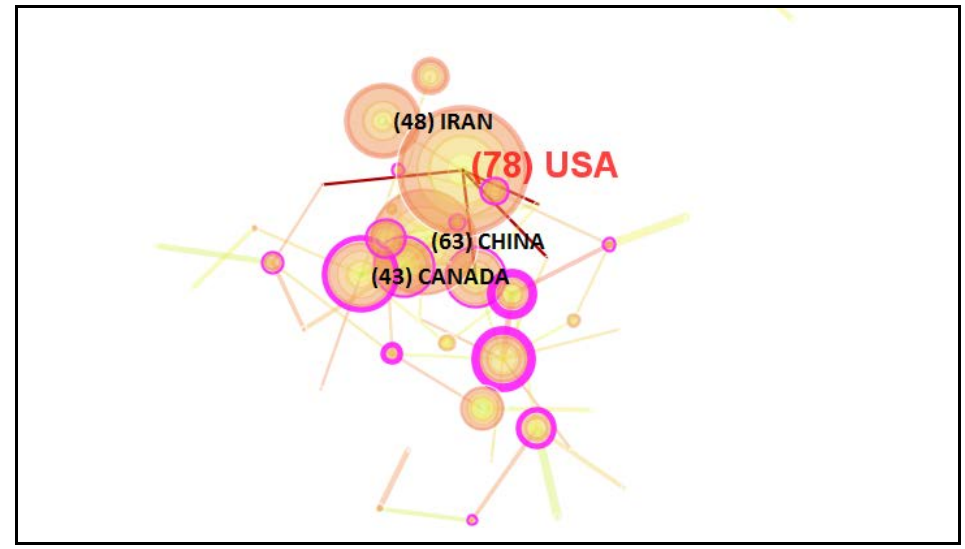

Figure 5: Network of Co-authorship by Country

There are numerous definitions for these companies. However, by uniting concepts from Balkin et al. (2000), Grinstein and Goldman (2006), Löfsten and Lindelöf (2005) and Machado et al. (2001), the conclusion is that they are organizations based on activities of development and production of innovations, based on the systematic application of scientific and technological knowledge and use of advanced and pioneering techniques. Its main inputs are the knowledge and technical-scientific information, present high expenses with Research \& Development, besides employing large amount of technical-scientific and engineering personnel.

The development of TBC's is due to the movement of Science Parks. The term Science Parks is designed to describe a private initiative with formal and operational links with universities, higher education institutions and research centers. It is designed for research and business development based on the sharing of knowledge of other organizations that participate in the technological pole, and which have an administrative function engaged with the transfer of technology and entrepreneurial skills to the companies located there (MACHADO et al., 2001).

Data available by Unesco (2016) indicate the number of parks in the most relevant countries in the co-author network: China 80, USA 72, Canada 13 and Iran 3. Organizational environment that naturally encourages national economy promotes innovation and demands the development of scientific knowledge of these countries.

\subsection{Analysis of the author citations network}

According to Foresti (1989), a description for citation analysis would be a part of Bibliometry responsible for investigating the relationships between citing documents and cited documents considering as units of analysis, integrally or in their 
various parts: author, title, geographical origin, year and Language of publication, etc. With the help of the Sci2Tool software, an Author Citation Network was created, which can be observed in Figure 6.

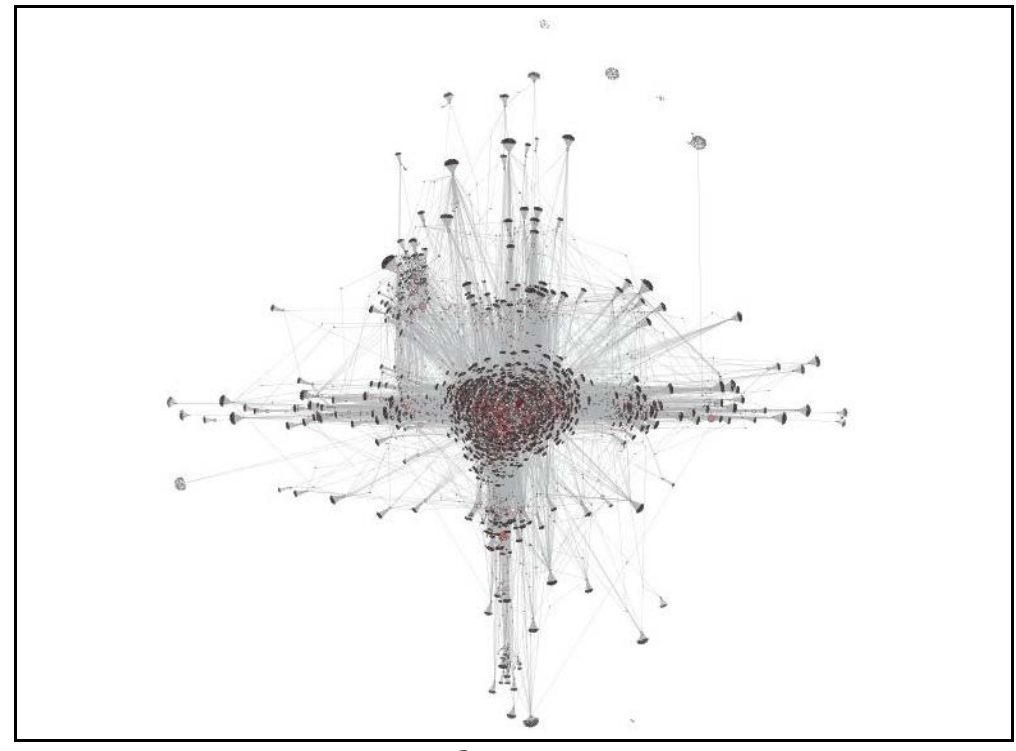

Figure 6: Citation Network

Approaching the Network of Quotations in its focus of greater density Figure 7 is obtained. In this, it is identified that the represented authors are analogous to those that are in the Report of Quotations. This report was extracted from the Web of Science online platform and is represented in Table 1.

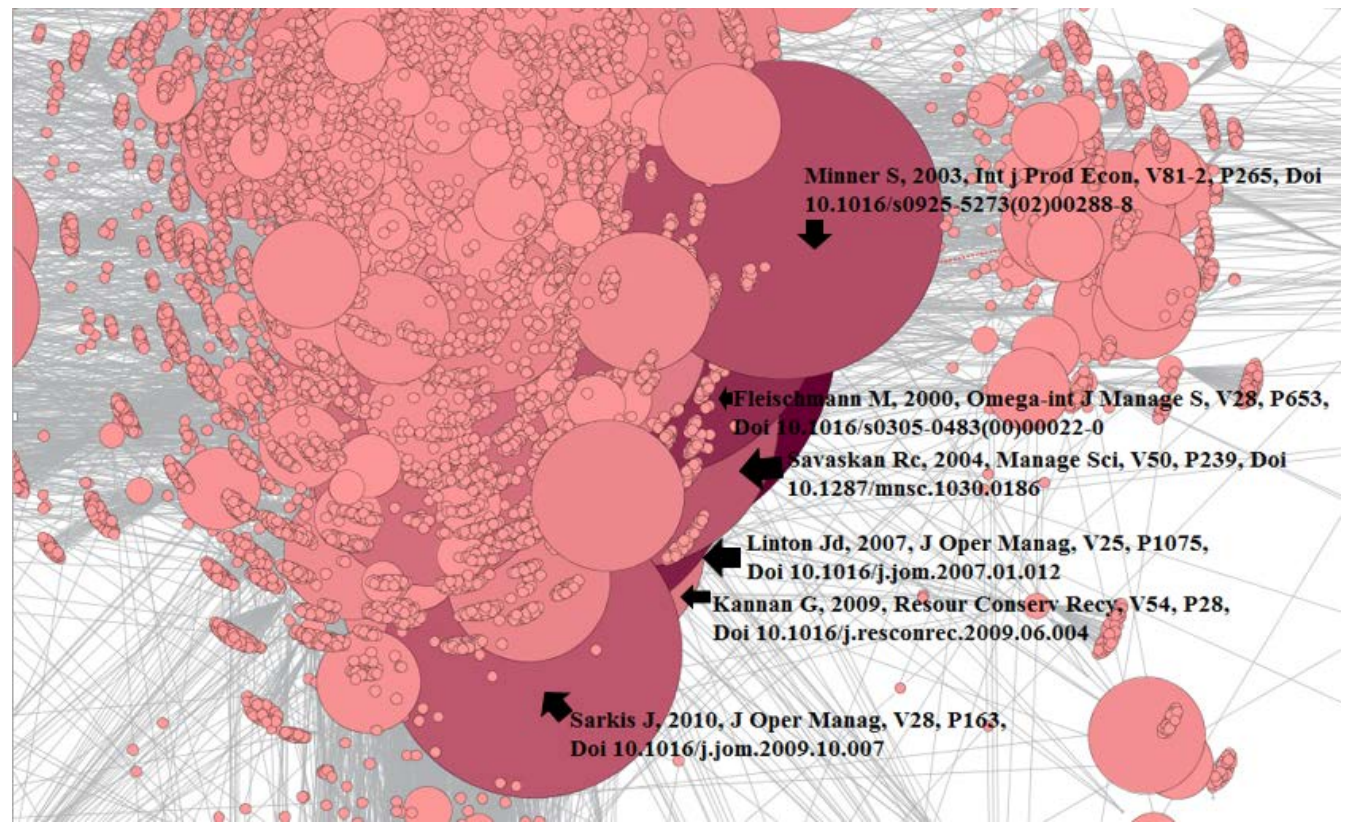

Figure 7: Citation Network Higher Density Focus

Table 1: Citations Report 
INDEPENDENT JOURNAL OF MANAGEMENT \& PRODUCTION (IJM\&P)

http://www.ijmp.jor.br

v. 9, n. 2, April - June 2018

ISSN: 2236-269X

DOI: 10.14807/ijmp.v9i2.689

\begin{tabular}{|c|c|c|c|c|}
\hline & Title & Authors & Citations & $\begin{array}{c}\text { Publication } \\
\text { Year }\end{array}$ \\
\hline 1 & $\begin{array}{l}\text { Quantitative models for } \\
\text { reverse logistics: A } \\
\text { review }\end{array}$ & $\begin{array}{l}\text { Fleischmann, M; } \\
\text { BloemhofRuwaard, JM; } \\
\text { Dekker, R; VanderLaan, } \\
\text { E; VanNunen, JAEE; } \\
\text { VanWassenhove, LN. }\end{array}$ & 727 & 1997 \\
\hline 2 & $\begin{array}{lr}\text { Closed-loop } & \text { supply } \\
\text { chain models } & \text { with } \\
\text { product } & \\
\text { remanufacturing } & \end{array}$ & $\begin{array}{ll}\text { Savaskan, } & \text { RC; } \\
\text { Bhattacharya, S; } & \text { Van } \\
\text { Wassenhove, LN. } & \end{array}$ & 561 & 2004 \\
\hline 3 & $\begin{array}{l}\text { Green supply-chain } \\
\text { management: A satate- } \\
\text { of-the-art } \quad \text { literature } \\
\text { review }\end{array}$ & Srivastava, Samir K. & 560 & 2007 \\
\hline 4 & $\begin{array}{l}\text { Facility location and } \\
\text { supply } \\
\text { management - A review }\end{array}$ & $\begin{array}{l}\text { Melo, M. T; Nickel, S; } \\
\text { Saldanha-da-Gama, F. }\end{array}$ & 368 & 2009 \\
\hline 5 & $\begin{array}{l}\text { A characterisation of } \\
\text { logistics network for } \\
\text { product recovery }\end{array}$ & $\begin{array}{l}\text { Fleischmann, M; Krikke, } \\
\text { HR; Dekker, R; Flapper, } \\
\text { SDP. }\end{array}$ & 313 & 2000 \\
\hline 6 & $\begin{array}{l}\text { Sustainable supply } \\
\text { chain: An introduction }\end{array}$ & $\begin{array}{l}\text { Linton, Johnathan D; } \\
\text { Klassen, } \\
\text { Jayaraman, } \\
\text { Vaidyanathan. }\end{array}$ & 293 & 2007 \\
\hline 7 & $\begin{array}{lr}\text { A closed-loop } & \text { logistics } \\
\text { model } & \text { for } \\
\text { remanufacturing } & \end{array}$ & $\begin{array}{l}\text { Jayaraman, V; Guide, } \\
\text { VDR; Srivastava, R. }\end{array}$ & 268 & 1999 \\
\hline 8 & $\begin{array}{l}\text { The impact of product } \\
\text { recovery on logistics } \\
\text { network design }\end{array}$ & $\begin{array}{l}\text { Fleischmann, } \\
\text { Beullens, P; Bloemhof- } \\
\text { Ruwaard, JM; Van } \\
\text { Wassenhove, LN. }\end{array}$ & 253 & 2001 \\
\hline
\end{tabular}

These results indicate the importance of the authors in the academic field of Reverse Logistics, since they represent the main sources of data chosen by the scientific community. One can interpret such prominence of these authors through the idea of Evolution of Knowledge. The production of knowledge is part of an aspect of human existence and according to Souza and Morais (2012) one experiences an era characterized by the technical-scientific revolution that greatly facilitated access to information.

However, even if a wide variety of study material is available, each new topic stems from a problem that has repercussions on reflection, search for explanations and solutions. Following this line of thought, it can be highlighted that the problematic Reverse Logistics had its first reflections and solutions from the authors like Fleishmann M., Savaska R., because their studies deal with a base reference for the 
DOI: 10.14807/ijmp.v9i2.689

development of research on Reverse Logistics.

Another co-cited network is co-citation and is represented in Figure 8. The cocitation analysis studies are based on the co-occurrence of two authors or documents of scientific production and highlight the knowledge structure of a given front, according to the perception of the citing community.

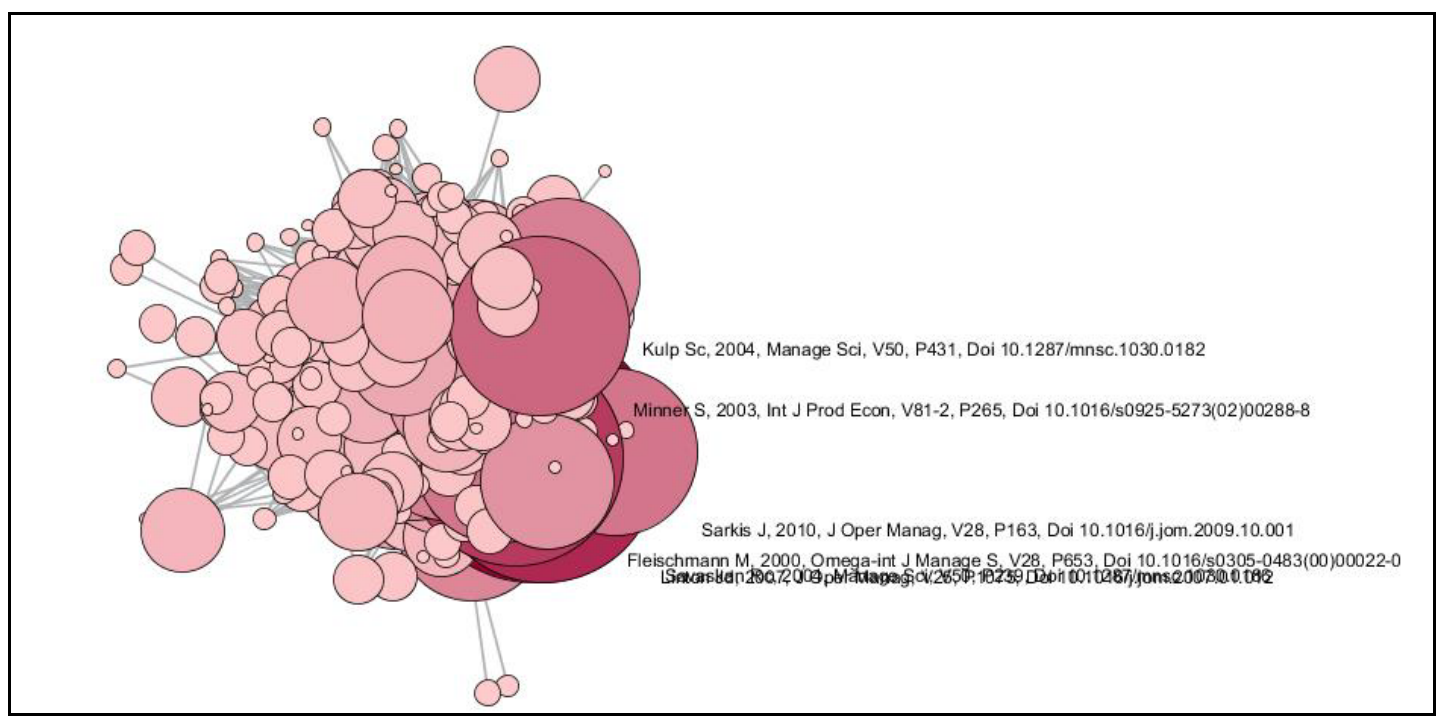

Figure 8: Co-Citation Network

The co-citation analysis refers to the co-occurrence of two authors or publications, based on the premise that when two authors or publications are cited together in a later publication there are indications of subject proximity between those cited from the perspective of citing. Thus, the number of times that two articles, authors, and journals are cited together in a third article is counted (MIGUEL et al., 2008).

From the network, it is observed that M. Fleischmann is one of the main authors of citations and in the network of citations, he is one of the largest nodes in the Network of Citations, once again showing its significant influence in the academic field when it comes to the topic Reverse Logistics.

\section{FINAL CONSIDERATIONS}

The paper contributes to a bibliometric analysis of the subject Reverse Logistics using bibliometric networks and applying Social Network Analysis. It is verified when, looking for other literary analysis, that this type of study using bibliometric networks is novel, being rare the studies that explore the same segment 
of ideas, even more when it comes to the subject in question.

Another contribution of the research is that this analysis allowed identifying the main areas where the reverse logistics is approached, as well as, the interface of the subject with other areas; it allowed to visualize groups of researches, the existing collaboration between different authors and countries, the most cited papers and those that have proximity of subjects. Given the analysis presented, the research also contributes to the people who are starting the research on the subject, as it assists in the visualization of the state of the art. As a secondary contribution to this study, it is highlighted the systematization of the methodological procedure that integrates bibliometric analysis and analysis of social networks.

The use of bibliometric networks and the analysis of social networks are important, since they allow to identify patterns of cooperation and productivity of researchers, besides helping to better understand themes, concepts and relationships between various subjects.

Thus, from the results on citations it was possible to identify the author responsible for presenting theoretical contributions to the field of knowledge of reverse logistics. This author is Fleishmann. Its importance is shown to contain three related studies among the ten most cited. The results of the analytical treatment corroborate with the descriptive report of the number of citations, evidencing the importance of the author.

With regard to co-authorship networks, there is collaboration between authors from different universities and countries. This shows that there are no groups of institutions or countries segmenting knowledge.

The co-citation network has again identified that the author Fleishmann is the main node of the network. This means that it is the author that most connects different groups of articles, that is, it represents the knowledge base for different areas of research.

The research has some limitations; among them is the fact that some analysis have not been explored, for example the modeling where the data models are grouped in descriptive and of processes (WEINGART et al., 2010). Therefore, it is recommended that future researchers address these variables. In addition, as a suggestion, the same methodology of the study is highlighted, but on other research 
DOI: 10.14807/ijmp.v9i2.689

fronts such as the Green Logistics.

\section{REFERENCES}

ADLMAIER, D.; SELLITTO, M. A. (2007) Embalagens retornáveis para transporte de bens manufaturados: um estudo de caso em logística reversa. Production Journal, v. 17, n. 2, p. 395-406.

AGRAWAL, S.; SINGH, R. K.; MURTAZA, Q. (2015) A literature review and perspectives in reverse logistics. Resources, Conservation and Recycling, v. 97, p. 76-92.

AUTRY, C. W.; DAUGHERTY, P. J.; GLENN RICHEY, R. (2001) The challenge of reverse logistics in catalog retailing. International Journal of Physical Distribution \& Logistics Management, v. 31, n.1, p. 26-37.

BALKIN, D. B.; MARKMAN, G. D.; GOMEZ-MEJIA, L. R. (2000) Is CEO pay in hightechnology firms related to innovation?. Academy of Management Journal, p. 1118-1129.

CHEN, C. (2006) CiteSpace II: detecting and visualizing emerging trends and transient patterns in scientific literature. Journal of the American Society for Information Science and Technology, v. 57, n. 3, p. 359-377.

COUNCIL OF SUPPLY CHAIN MANAGEMENT PROFESSIONAL - CSCMP (2015), Supply Chain Management Terms and Glossary, Available at: https://cscmp.org (accessed 30 nov 2016).

DAIM, T. U.; RUEDA, G.; MARTIN, H.; GERDSRI, P. (2006) Forecasting emerging technologies: use of bibliometrics and patent analysis. Technological Forecasting and Social Change, v. 73, n. 8, p. 981-1012.

DA SILVA, E. F.; DAMASCENO, L. F. F.; KAWAMOTO JÚNIOR, L. T. (2017) The reverse logistics importance in the management of residues of plastic packaging of lubricants and the program jogue limpo. Independent Journal of Management and Production, v. 8, n.5, p. 659-675.

FARINA, M. C. (2004) Análise de Redes Sociais. Programa de Pós-Graduação em Comunicação, Universidade Municipal de São Caetano do Sul (PPGCOMUSCS).

FLEISCHMANN, M. (2000) Quantitative Models for Reverse Logistics, Erasmus University Rotterdam, 209p.

FORESTI, N. A. (1990) Contribuição das revistas brasileiras de biblioteconomia e ciência da informação enquanto fonte de referência para a pesquisa. Ciência da Informação, v. 19, n. 1, p. 53-71.

GNYAWALI, D.; MADHAVAN, R. (2001) Cooperative networks and competitive dynamics: a structural embeddedness perspective. Academy of Management Review, v. 26, n. 3, p. 431-445.

GOVINDAN, K.; PALANIAPPAN M.; ZHU Q.; KANNAN, D. (2012) Analysis of third party reverse logistics provider using interpretive structural modelling. International Journal of Production Economics, v. 140, n. 1, p. 204-21. 
GOVINDAN, K.; SOLEIMANI, H.; KANNAN, D. (2015) Reverse logistics and closedloop supply chain: A comprehensive review to explore the future. European Journal of Operational Research, v. 240, n. 3, p. 603-626.

GRÁCIO, M. C. C.; DE OLIVEIRA, E. F. T. (2014) Estudos de Análise de Cocitação de Autores: uma abordagem teórico-metodológica para a compreensão de um domínio. Tendências da Pesquisa Brasileira em Ciência da Informação, v. 7, n. 1.

GRINSTEIN, A.; GOLDMAN, A. (2006) Characterizing the technology firm: An exploratory study. Research Policy, v. 35, n. 1, 121-143.

HE, Q. (1999) Knowledge discovery through co-word analysis. Library Trends, v. 48, p. 133-159.

KOBASHI, N.; SANTOS, R. (2006). Institucionalização da pesquisa científica no Brasil: cartografia temática e de redes sociais por meio de técnicas bibliométrica. TransInformação, v. 18, n. 1, p. 27-36.

LEITE, P. R. (2002). Logística Reversa: Nova área da Logística Empresarial. Revista Tecnologística, São Paulo, Ed. Publicare.

LIMA, M. Y. (2009) Redes de co-autoria científica no Programa de PósGraduação em Geociências da UFRGS. Dissertation (Master in Sociology). Rio Grande do Sul: PPGS-UFRGS, Available: http://www.lume.ufrgs.br. Access: 15/02/2017.

LÖFSTEN, H.; LINDELÖF, P. (2002) Science Parks and the growth of new technology-based firms-academic-industry links, innovation and markets. Research Policy, v. 31, n. 6, p. 859-876.

LOPES, S.; COSTA, M. T.; FERNÁNDEZ-LLIMÓS; AMANTE, M. J.; LOPES, P. F. (2012) A Bibliometria e a Avaliação da Produção Científica: indicadores e ferramentas. Actas dos Congressos Nacionais de Bibliotecários, Arquivistas e Documentalistas, v. 11, n. 1, p. 1-7.

MACHADO, S. A.; PIZYSIEZNING FILHO, J.; CARVALHO, M. M.; RABECHINI JUNIOR, R. (2001) MPEs de base tecnológica: conceituação, formas de financiamento e análise de casos brasileiros. São Paulo: Sebrae-SR.

MIGUEL, S.; MOYA-ANEGON, F.; HERRERO-SOLANA, V. (2008) A new approach to institutional domain analysis: Multilevel research fronts structure. Scientometrics, v. 74, n. 3, p. 331-344.

MORAES, D. G.; MORAES, S. V. M.; ROCHA, T. B.; EWALD, M. R. (2014) Life cycle assessment of cell phones in Brazil based on two reverse logistics scenarios. Production Journal, v. 24, n. 4, p. 735-741.

MUÑOZ-LEIVA, F.; VIEDMA-DEL-JESUS, M. I.; SÁNCHEZ-FERNÁNDEZ, J.; LÓPEZ-HERRERA, A. G. (2012). An application of co-word analysis and bibliometric maps for detecting the most highlighting themes in the consumer behaviour research from a longitudinal perspective. Quality \& Quantity, v. 46, n. 4, p. 1077-1095.

POKHAREL, S.; MUTHA, A. (2009) Perspectives in reverse logistics: a review. Resources, Conservation and Recycling, v. 53, n. 4, p. 175-182.

PRITCHARD, A. (1969) Statistical Bibliography or bibliometrics?. Jounal of Documentation, v. 25, n. 4, p. 348-349. 
RAVI, V.; SHANKAR, R. (2005) Analysis of interactions among the barriers of reverse logistics. Technological Forecasting and Social Change, v. 72, n. 8, p. 1011-1029.

ROGERS, D. S.; TIBBEN-LEMBKE, R. S. (1998) Goind Backwards: Reverse Logistics Trends and Practices. Center for Logistics Management, University of Nevada, Reno.

ROGERS, D. S.; TIBBEN-LEMBKE, R. S. (2001) An Examination of Reverse Logistics Practices. Journal of Business Logistics, v. 22, n. 2, p. 129-148.

SACOMANO NETO, M. (2004). Morfologia, propriedades e posicionamentos das redes: contribuições às análises interfirmas, In: SIMPÓSIO DE ENGENHARIA DE PRODUÇÃO. SIMPEP, 2004, Bauru. ANAIS... Bauru: UNESP, 2004.

SCI2TEAM, "SCIENCE OF SCIENCE (Sci2) TOOL", Indiana University and SciTech Strategies, Available at: https://sci2.cns.iu.edu. Access: 18/02/2017.

SILVA, A. B. O.; MATHEUS, R. F.; PARREIRAS, F. S.; PARREIRAS, T. A. S. (2006) Análise de redes sociais como metodologia de apoio para a discussão da interdisciplinaridade na ciência da informação. Ciência da Informação, v. 35, n. 1, p. 72-93.

SOUZA, M. F.; MORAIS A. S. (2012) Origem e Evolução do Conhecimento OEC. São Paulo, Ed. Acquerello.

THIERRY, M.; SALOMON, M.; NUNEN, J. V.; WASSENHOVE, L. V. (1995) Strategic Issues in Product Recovery Management. California Management Review, v. 37, n. 2, p. 114-135.

UNESCO. Science Parks around the World. Science Policy, 2016, Available at: http://www.unesco.org/new/en/natural-sciences/science-technology/universityindustry-partnerships/science-parks-around-the-world. Access:: 28/09/2016).

WEINGART, S.; GUO, H.; BÖRNER, K. (2010). Science of Science (Sci2) tool user manual, Cyberinfrastructure for Network Science Center, School of Library and Information Science, Indiana University, Bloomington. Version Alpha 3, Available at: https://sci2.cns.iu.edu/docs/Sci2_Tutorial_003.pdf. Access: 12/01/2017.

ZARE-FARASHBANDI, F.; GERAEI, E.; SIAMAKI, S. (2014). Study of co-authorship network. Journal of Research in Medical Sciences, v. 19, n. 1, p. 41-46. 